УДК 930; ББК 63.3; DOI https://doi.org/10.21638/spbu19.2021.113

Ch. J. Halperin

\title{
AN ARTIFACT OF SOVIET HISTORIOGRAPHY: OCHERKI ISTORII ISTORICHESKOY NAUKI V SSSR
}

The title of Alexey Yurchak's study of the last Soviet generation brilliantly articulates how people in the Soviet Union reacted when the Soviet Union fell apart: «everything was forever, until it was no more» ${ }^{1}$. According to Yurchak, the social characteristics of the last Soviet generation explain how its members thought the Soviet system would never end, but were not surprised by its demise. Historians specializing in Russia who were trained and began their academic research during the Cold War probably thought that Soviet historiography would last forever too. One of the major functions of Western studies of Russian history at that time was to critique Soviet historiography. Of course the break-up of the Soviet Union and the demise of Communist Party rule automatically meant the end of Soviet historiography.

Aside from its adhesion to Marxist-Leninism, the Soviet historical establishment from the mid-1950s on had several salient features: enormous expertise in all areas of history, authoritarianism, and wealth. The Academy of Sciences of the USSR consisted of a plethora of institutes and branches (filialy), a structure reproduced in every Union republic. The historical profession enjoyed considerable financial support for its research and publications. Therefore the academic leadership could mobilize by command the human and material resources to conduct large-scale projects to produce multi-authored, multi-volume works which could be published in impressive print runs (tirazhy) at modest prices ${ }^{2}$. Publishers were subsidized,

${ }^{1}$ Yurchak A. Everything Was Forever, Until It Was No More: The Last Soviet Generation. Princeton, 2006.

${ }^{2}$ The revisionist historian Eduard Burdzhalov, who had frequent conflicts with academic authorities, criticized the preoccupation with multi-authored multi-volume publications as deliberately stifling individual creativity in historical research (Markwick $R$. D. Rewriting History in Soviet Russia: The Politics of Revisionist Historiography, 1956-1974. Houndmills, Basingstoke, Hampshire, 2001. P. 55). Ironically, Markwick cites the increase in the number of such collective works as an indicator of the progress of Soviet historiography (Markwick R. D. Rewriting History... P. 69; Byrnes R. F. Some Perspectives on the Soviet Ferment Concerning Soviet History // Facing Up to the Past: Soviet Historiography under Perestroika / Ed. T. Ito. Sapporo, Japan, 1989. P. 15-16)

(C) Ch. J. Halperin, 2021 
so no project could be turned down on economic reasons or dim hopes for an adequate audience. The Academy of Sciences had its own publishing outlets. No one asked to participate in a project could decline to do so, which must evoke envy in editors of comparable projects in the West who fail to recruit some of the scholars they had hoped to because they were not interested or not available. As a result of this command structure and support system, the Soviet historical establishment in its heyday produced a plethora of multi-volume surveys ${ }^{3}$. A quarter of a century after the collapse of the Soviet Union these aspects of Soviet historical study deserve to be remembered.

\section{INTRODUCTION: OCHERKI ISTORII ISTORICHESKOY NAUKI V SSSR}

This essay seeks to remind historians of Russia of those features of Soviet historiography by examining an artifact of its output, the five-volume Ocherki istorii istoricheskoy nauki $v$ SSSR published between 1955 and 1985, all in Moscow, the first four by the Publisher (Izdatel'stvo) of the Academy of Sciences of the USSR, the last by Nauka, also an Academy of Sciences publisher ${ }^{4}$. The series remained unfinished. The Soviet Union ran out of time before the project could be completed. The scope of the project was appropriately grandiose: to encompass studies of historical writing from time immemorial to the end of the 1960s on all the territories that were currently part of the Soviet Union.

The chronological division of the volumes legitimately follows the increasing production of historiography in more recent times, but also reflects a periodization generated by Marxist ideology and Soviet identity. Volume One started with ancient times and proceeded to the middle of the $19^{\text {th }}$ century; Volume Two covered the second half of the $19^{\text {th }}$ century up to when Lenin started writing; Volume Three the period of imperialism in Russia, coterminous with that of Lenin's literary output, up to 1917; Volume Four from the 1917 revolution until the mid-1930s; and Volume Five from the mid-1930s to the end of the 1960s with the proclamation that the Soviet Union had entered the stage of socialism. The partisan and ideological content of the volumes increased from volume to volume.

The dates of publication of the five volumes contain our first anomaly. The shortest gap between the appearance of volumes is three years, so I assume that research on the project

criticized Soviet scholarship for producing «thousands of unread copies of multi-author, multivolume historical accounts» of total mediocrity, «colorless descriptions of alleged achievements by anonymous teams». Such there were, but I would not apply that description to Ocherki istorii istoricheskoy nauki $v$ SSSR, or to several other such series, such as the history of the city of Moscow and the history of the USSR (see next note). Moreover, these works were not anonymous; they recorded the names of the authors of each chapter and sub-chapter.

${ }^{3}$ For example: Очерки истории СССР: В 9 т. Москва: Издательство АН СССР, 1953-1958; Markwick R. D. Rewriting History... P. 69. - Markwick mentions the ten-volume Universal History published between 1956 and 1965, which contained almost $21 / 2$ million words by 400 writers, editors, consultants, and assistants.

${ }^{4}$ Очерки истории исторической науки в СССР(Ocherki istorii istoricheskoi nauki v SSSR): В 5 т. T. 1. Москва: Издательство АН СССР, 1955. 692 с.; Т. 2. Москва: Издательство АН СССР, 1960. 852 с.; Т. 3. Москва: Издательство АН СССР, 1963. 832 с.; Т. 4. Москва: Издательство АН СССР, 1966. 854 с.; Т. 5. Москва: Наука, 1985. 606 с. - Cherepnin died in 1977, so he must have made his editorial contribution long before Volume Five appeared. For convenience references to these volumes will be given in parentheses in the text by volume number and pages. 
began no later than 1952. The first volume appeared in 1955, the second, 1960, the third 1963, the fourth 1966, and the fifth 1985 . Volume Five saw the light of day only nineteen years after Volume Four. The editors of Volume Five did not explain the delay, which will be discussed below.

The length of the volumes and their press runs attest to the amount of effort expended on this ambitious project (Table 1), but also contain our second anomaly.

Table 1. Volume, pagination and printed copies ${ }^{5}$

\begin{tabular}{|c|c|c|c|}
\hline Volume & Total pp. & Pages of text & Printed copies \\
\hline 1 & 692 & 651 & 10,000 \\
\hline 2 & 852 & 838 & 5,000 \\
\hline 3 & 832 & 760 & 2,200 \\
\hline 4 & 854 & 826 & 3,000 \\
\hline 5 & 606 & 587 & 1,700 \\
\hline Totals: & 3,836 & 3,662 & \\
\hline
\end{tabular}

The print run of Volume One is almost an outlier, double the next greatest print run. The average print run of Volumes Two through Five is 2,975, compared to the 10,000 copies of Volume One. Indeed, the total number of copies of Volumes Two through Five is less than $20 \%$ above the press run of Volume One alone, 11,900 versus 10,000. Yet the press runs do not show a consistent decline. Although the lowest press run belongs to Volume Five, Volume Four's press run was higher than Volume Three's. Like the shift in publishers for Volume Five, the peculiarities in the numbers of copies printed remains a mystery. The print run does not correlate with the length of each volume. It is true that Volume One was shorter than Volumes Two, Three, and Four, but it was longer than Volume Five. Over 3,500 pages of text for the five-volume set reflects the breadth of the project and the thoroughness of its implementation.

At no point did the project skimp on its commitment of human resources, either of editors or contributors. Each volume had an Editor-in-Chief (in Russian, «Responsible Editor», Otvetstvenniy redaktor), but only Volume Five also had a Deputy Editor (zamestitel' to the Responsible Editor). The Editors-in-Chief of Volumes One through Four were aided by two, five, five, and nine additional editors respectively; the Editor-in-Chief and Deputy Editor of Volume Five were assisted by twelve additional editors. The ever-increasing complexity of the subject matter might explain the rising number of associate editors. The additional of a Deputy to the Editor-in-Chief in Volume Five might be related to the advancing age of Editor-in-Chief M. V. Nechkina, who had already served in that capacity for Volumes Two through Four; she was born in 1893 and died in 1985. Her age might have affected her ability to perform the final editing, but we do not know how long before 1985 the volume was already basically completed. There was significant continuity among the editorship. The Editor-in-Chief of Volume One, M. N. Tikhomirov, was an associate editor of Volume Two; born in 1901, he died

${ }^{5}$ The difference between total pages and pages of text in all volumes represents the Index. Volume Three also contained a bibliography of all works cited in Volumes One to Three, which accounts for the much greater page differential between text length and total length. 
in 1965. Like Nechkina and Tikhomirov, editors not rarely served on more than volume. Of 21 editors, one served as editor on all five volumes, two on four volumes, one on three, and three on two volumes (Table 2).

Table 2. Editors

\begin{tabular}{|c|c|c|c|}
\hline Editor & Volumes & Editor & Volumes \\
\hline Alekseeva, G. D. & 4 & Ivanova, I. V. & 5 \\
\hline Alpatov, M. A. & $1,2,3,4,5$ & Naumov, V. P. & 5 \\
\hline Berkhina, G. V. & 4 & Nechkina, M. V. & $2,3,4,5$ \\
\hline Berkhin, I. B. & 5 & Nikiforov, V. N. & 5 \\
\hline Buganov, V. I. & 5 & Sherstobitov, V. P. & 5 \\
\hline Cherepnin, L. V. & 4,5 & Sidorov, A. L. & 1 \\
\hline Dubrovskiy, S. M. & 2,3 & Stanislavskaya, A. M. & $2,3,4$ \\
\hline Dunaevskiy, A. M. & 4,5 & Tarnovskiy, K. N. & 5 \\
\hline Golikov, G. N. & 4 & Tikhomirov, M. N. & 1,2 \\
\hline Gorodetskiy, E. N. & $3,4,5$ & Veber, B. G. & $2,3,4,5$ \\
\hline Ignatenko, T. A. & 5 & & \\
\hline
\end{tabular}

Such editorial continuity must have contributed to the integration of the volumes. Chapters in the same volume cross-reference each other; chapters in later volumes cross-reference material in earlier volumes; chapters in earlier volumes even anticipate chapters in later volumes. The editors and contributors realized that the active academic lives of some authors discussed in the series crossed the period divides of its volumes, and took a practical approach to the problem by sometimes breaching such divides and always cross-referencing discussions, for example, on M. Kovalevskiy (T. 3. Pp. 449-497). In Volume Five Cherepnin even cited Soviet reviews of Volume One (T. 5. P. 21).

Usually editors were also contributors, so I have not cross-indexed them. Nor have I quantified how many contributors wrote more than one segment - chapter or sub-chapter — in a given volume. As one would expect from the variety of material per volume, the numbers of contributors are impressive (Table 3).

Table 3: Number of Contributors per volume

Vo

Number of contributors
41
40
54
43
29

Over the five volumes, 130 different authors contributed (Appendix 1). Of these, 80 contributed to one volume, 28 to two volumes, 19 to three volumes ${ }^{6}$, and 3 to four

${ }^{6}$ Alekseeva, Alpatov, Artsikhovskiy, Danilov, Draudin, Gabashvili, Gal'perin, Gorodetskiy, Guliev, Yatsunskiy, Illeritskiy, Ioninas, Nikitin, Pertsev, Semenov, Shakhmatov, Sivkov, Stanislavskaya, Tokarev. 
volumes $^{7}$. The authors of chapters or sub-chapters in multiple — usually successive volumes contributed yet another layer of continuity to the endeavor.

In their «Preface» to Volume One, the editors stated that the greatest quantity of material pertained to Russian (russkaia) historiography, which was appropriate because Russian historiography from the $18^{\text {th }}$ century on took the lead among all peoples living in the Russian Empire and later the Soviet Union (T. 1. Pp. 3-4). «Russian» here refers to the nationality of the historians under discussion, not to the subject matter. The volumes encompass works by Russian historians not just on Russian history but on the history of non-Russians, not only those of nationalities living within what was then the Soviet Union, but everywhere. Sections in various volumes covered works by Russian historians on ancient, medieval, early modern, and modern European history as well as of the Orient, the Near East, including India and Tibet, the Middle East, and the Far East beyond the borders of Imperial Russia and the Soviet Union, that is, outside Siberia, a subject of separate attention as well, including China, Japan, Korea, and Mongolia. Of the non-Russians living on Imperial Russian or Soviet territory, sections were devoted to the history of Ukraine and Belarus, and sometimes to Moldavia; Latvia, Lithuania, and Estonia; Azerbaijan, Georgia; and Armenia; and Kazakhstan, Uzbekistan, Tajikistan, Turkmenistan, and Kirghizistan. The scope of the project was matched by the ability of the editors to mobilize Soviet expertise in all these areas of historical knowledge. In addition, chapters were devoted to auxiliary historical disciplines, including archeology, archeography, numismatics, paleography, sigillography (sphragistics), chronology, diplomatics, genealogy, heraldry, filigranology, and historical geography. The institutional structure of historical study - universities, academies of science, institutes - and their supporting organizations - archives, museums, societies - also receive their due. Only a centralized, well-funded historical establishment with comprehensive substantive specializations could attempt such an undertaking. The ambitiousness of the vision of the editors cannot be diminished by the fact that the project was not completed; what was achieved remains impressive despite what was left on the drawing board.

Each volume must be examined separately. No one article could cover their contents comprehensively. There is no point in regurgitating what was entirely predictable, such as the dismissal of Mykhailo Hrushevsky as a bourgeois nationalist or the elevation of Lenin to the status of brilliant historian. I treat only a handful of selective, but I hope illustrative, topics.

\section{Volume One (1955): Ancient Times to Mid-19 ${ }^{\mathrm{TH}}$ Century}

The editors note that the geographic coverage of this volume was incomplete, missing the Karelo-Finnish SSR and the Moldavian SSR (T. 1. P. 3. Note 1). (Moldavia was discussed in Volume Two.) It included everyone else geographically within the Russian Empire, the Baltic region, the Caucasus, and Central Asia, and outside the Russian Empire, Byzantine studies, Slavic Studies, the Near and Middle East, and the Far East, as well as the auxiliary historical disciplines and the history of historical institutions.

In discussing the earliest history of the Slavs and peoples of the Caucasus up to the $10^{\text {th }}$ century, the authors pay homage to the value of the oral historical works of the «people» (narod), including but not limited to the East Slavs, Georgians and Armenians (T. 1. Pp. 17-47), and

${ }^{7}$ Cherepnin, Smirnov, Udal'tsova. 
Turkmen (T. 1. P. 649) ${ }^{8}$. Given the Soviet attention to folklore in studying East Slavic history during the Kievan and medieval periods of Rus' history, this does not come as a surprise, but it confirms a point that might sometimes get lost in works confined to Russian historiography, namely, that the concepts and methods of historians of the East Slavs in the Soviet Union were shared by Soviet historians of the rest of the world ${ }^{9}$.

A negative word ${ }^{10}$ in Volume One is «cosmopolitan», used in the «Introduction» to describe people who want Russia to ape the bourgeois West (T. 1. P. 14); by Predtechenskiy on Pogodin for ascribing Russian folklore to Scandinavian sagas, (T. 1. P. 320) and the object of Polevoy's ire as denigrating patriotism and loyalty (T. 1. P. 332); according to Rubinshtein as the object of Belinskiy's animosity against liberal Westernizers (T. 1. P. 377). The oddity is that according to Illeritskiy, Herzen thought that all nations could contribute to world culture, so he was opposed to cosmopolitanism (T. 1. P. 394), but to me that all nations can contribute to world culture is cosmopolitanism. According to Alpatov, world-historian Eshevskiy thought that the multi-national Roman Empire needed a cosmopolitan religion like Christianity as a unifying force because paganism would not suffice (T. 1. P. 459). To the authors of Volume One, cosmopolitanism necessarily entails de-nationalization. If any of its contributors remembered the anti-Semitic connotation of usage of the word in the late 1940s, he kept it to himself.

Tikhomirov makes the interesting observation that in Kievan Rus' historiography was written in the native language, like in Armenia and Georgia, but unlike in Western Europe (he could have added Eastern Europe) in Latin and in Central Asia in Arabic (T. 1. P. 60). This was a very apposite remark in a volume that includes Kievan Rus', Central Asia, and the Caucasus, of which Tikhomirov was not just an editor but Editor-in-Chief.

The sub-chapter on Ukraine by Boyko and Dyadenko omits Jewish historiography on Bogdan Khmel'nytskiy (T. 1. Pp. 107-113).

It is noteworthy that despite the scandal over Rubinshtein's book on Russian historiography, he contributed sub-chapters on the State School and Sergey Solov'ev to Volume One (T. 1. Pp. 338-366) ${ }^{11}$. Reading Rubinshtein on the State School elicits a comparison that neither he nor Predtechenskiy articulated, perhaps because it is so obvious: just as the Slavophiles used West European romanticism to distinguish Russia from Europe, so the State School used Hegelianism to accomplish the same result.

One could not hope for a more qualified expert to discuss archeological research than Artsikhovskiy (T. 1. Pp. 523-535); he also did so in Volume Two (T. 2. Pp. 614-632) and Volume Three (T. 3. Pp. 586-596). However, his contributions lack illustrations. There are no illustrations in any of the volumes, obviously a policy decision, but one which is particularly unfortunate in dealing with archeology.

${ }^{8}$ The seeming exception here is Shakhmatov on Kazakhistan criticizing historians who accept feudal legends (legendy i predaniia) (1: 650), but «feudal» legends are not «popular» (narodnye) oral sources.

${ }^{9}$ Veber's chapter on (early modern and) modern European history in Volume Two (T. 2. Pp. 393-483) illustrates this phenomenon extremely well.

${ }_{10}$ The most ubiquitous negative word in the series is «zakhvatchik»; see: Halperin C. J. Zakhvatchiki, Soviet Historiography, and the Tatars: A Note // Vestnik Sankt-Peterburgskogo gosudarstvennogo universiteta. Seriya 2: Istoriya. 2019. Vol. 64. No. 4. Pp. 1429-1439.

${ }^{11}$ In Chapter 1 of Volume Five from 1985 (see below) Cherepnin wrote that criticism of Rubinshtein's textbook on Russian historiography was not always objective, but the discussion was productive (T. 5. P. 20). 


\section{Volume Two (1960): Mid-19 ${ }^{\text {TH }}$ CENTURy TO LeNIN}

Volume Two emulates the geographic, chronological, and disciplinary scope of Volume One, with as promised a sub-chapter on Moldavia (but no section on Karelia) and new subchapters on the Tatars (Tataria) and Siberia (Sibir'). A sub-chapter on Estonia was delayed to Volume Three (T. 2. P. 5).

There is a rare typographical error in the «Table of Contents» (T. 2. P. 852) giving the first page of Chapter 6 on the Middle Ages as 328 instead of 323.

The highlights in the treatment of $19^{\text {th }}$-century non-Marxist thought include Koz'min on the multiple influences on and complex ever-changing views of Shchapov (T. 2. Pp. 66-80), Illeritskiy on the State School's idealization of the state and use of Hegel (T. 2. Pp. 103-128), and Stanislavskaya on Kostomarov, once you get past the rote denunciation of him as a bourgeois-liberal Ukrainian nationalist, which dissects his uncritical use of forged or unreliable sources to construct romantic narratives (T. 2. Pp. 129-146). The discussion of Klyuchevskiy by Cherepnin (T. 2. Pp. 146-170) is uninspired. Cherepnin also wrote the pages on Klyuchevskiy's contribution to historiography (T. 2. Pp. 564-568). In his informative subchapter on source-study, Kashtanov intriguingly commented that Klyuchevskiy fetishized hagiography the same way that Platonov did Time of Troubles accounts (T. 2. Pp. 575-595).

Korostovtsev included Semitic studies in his sub-chapter on Ancient Near Eastern history, and recounts how Kokovstsev mobilized his scholarly expertise to give the lie to the ritual slaughter accusations at the $1913 \mathrm{Kiev}$ Beilis trial, thus opposing the Black Hundreds (T. 2. Pp. 298-299). There is nothing in this short sub-chapter (T. 2. Pp. 292-299) that indicates that its author was a Marxist.

Given Soviet historical, literary and artistic aversion to «foreign» influence on Rus'/Russian culture, it is no surprise that Artsikhovskiy's discussion of archeology in this volume criticizes Kondakov for exaggerating Byzantine influence on Rus' art, but he also wrongly accuses Kondakov of ignoring Oriental art (T. 2. P. 621).

«Cosmopolitanism» recurs once in Volume Two in Tokarev's sub-chapter on ethnography. He accuses ethnographers who adhered to the diffusion theory of folklore of supporting unscientific cosmopolitanism by rejecting the unique elements in every culture. Unique folklore to them reflected foreign influence (T. 2. P. 647).

Reading Ocherki istorii istoricheskoy nauki v SSSR is a not-necessarily pleasant reminder of how dull, lifeless, and formulaic most Soviet historical prose was; the price of clarity of expression was monotony of expression. It is therefore a pleasure to quote two colorful turns of phrase that somehow made it past the copy-editors of Volume Two. Draudin described the rising Latvian bourgeoisie as wanting their «place in the sun» (mesto pod solntsem) (T. 2. P. 737). Gasanov and Guliev describe grave-robbers as «hunters for easy profit» (okhotniki do legkoy nazhivy), the equivalent of the English «quick-profit hunters» (T. 2. P. 778).

The treatment in Volume Two of the great orientalist Bartol'd is a forerunner of the «yes, but» paradigm of treating ambiguous authors, not just historians, in subsequent volumes. Bartol'd is described by two authors as a bourgeois historian who made great contributions to Oriental Studies, Nepomnin on Uzbekistan (T. 2. P. 796) and Semenov on Tadzhikistan (T. 2. P. 907). It helps that he did not emigrate and therefore used his expertise to train future Marxist Soviet oriental specialists. 


\section{Volume Three (1963): Mid-19 ${ }^{\text {TH }}$ CENTURy to 1917}

Volume Three also followed the chronological, geographical, and disciplinary template of Volume One, although the editors apologized that for lack of space they could not include historical research on all foreign countries. The omitted subjects would be dealt with in Volume Four (T. 3. P. 7).

Volume Three contains pages on Mongolia (T. 3. Pp. 553-555) identified in Volume Four as written by Shastina, whose name was inadvertently omitted (T. 4. P. 786. Note *). The discussion of Estonia during the capitalist period by Iansen omitted from Volume Two for technical reasons and scheduled for inclusion in Volume Three did indeed appear in Volume Three (T. 3. Pp. 682-686).

Part Two of Volume Three is entitled «The Crisis of Bourgeois Historiography» (title page, T. 3. P. 237). The «crisis» to which it refers is the failure to accept Marxist historical theory and thus the inability to explain the success of the Bolshevik Revolution. This is obviously not the «crisis» of historiography as understood by Western historians, occasioned by postmodernism. This distinction must be kept constantly in mind in reading Cherepnin's chapter on the main elements of the «crisis» (T. 3. Pp. 239-278).

Pokrovskiy was partially rehabilitated in $1961^{12}$. The evaluation of his role in the development of Marxist historiography in this and later volumes conforms to the «yes, but» model previously applied to Bartol'd. Pokrovskiy made many mistakes, notably the theory of commercial capitalism, but he nevertheless made great contributions institutionally and substantively to Soviet historiography. This view was shared by Dubrovskiy in his panegyric to Lenin's contribution to Russian history (T. 3. P. 63) and his chapter on Pokrovskiy (T. 3. Pp. 218-236) ${ }^{13}$.

As mentioned above, pre-Revolutionary historians who remained in the Soviet Union and trained their successors, even if they never converted to Marxism, receive respectful treatment. Not so emigres, as evidenced by references to the reactionary and anti-Soviet classicist Mikhail Rostovtsev, who did emigrate, by Putnyn' on studies of ancient Greek history (T. 3. P. 387) and Mashkin on studies of Roman history (T. 3. P. 400), and Paul Vinogradov, who «betrayed» his fatherland (rodina) by emigrating, according to Alpatov on medieval history (T. 3. P. 420).

Smirnov goes even further than his colleagues in Volume Two in declaring that Bartol'd, like Krachkovskiy, did not reach the apex of his research talents until after the Soviet revolution (T. 3. Pp. 543-544) ${ }^{14}$, notwithstanding the uniform opinion of Soviet orientalists, reiterated by Gal'perin and Nikiforov discussing the Far East, that Bartol'd ignored the destructive impact of the Mongols on Central Asia (T. 3. P. 554).

The «yes, but» paradigm governed treatment of the founder of the comparative-historical methodology of studying Rus' chronicles Alexey Shakhmatov, who, despite contradictions and his bourgeois philosophy of history, still rates as a great scholar of world-wide importance according to Kashtanov on source-study (T. 3. Pp. 565-568).

Artsikhovskiy mentions in passing that archeologist Vikentiy Vyacheslavovich Khvoyka (Čeněk Chvojka) was a Czech by origin who migrated to Imperial Russia (T. 3. P. 591).

${ }_{12}$ Enteen G. M. Soviet Historians Review Their Own Past: The Rehabilitation of M. N. Pokrovsky // Soviet Studies. 1969. Vol. 20. No. 3. P. 306-320.

${ }^{13}$ On this chapter see: Enteen G. M. Soviet Historians Review... P. 307.

${ }^{14}$ Bartold first published «Turkestan in the time of the Mongol Conquests» in 1898. 
German historians who found employment in Russia during the $18^{\text {th }}$ century are well-known, but it would be interesting to know if there were other immigrants in all disciplines, not just history, during the $19^{\text {th }}$ century. Grosul and Mokov mentioned two Romanians who moved to Russia, joined the Populists, were imprisoned, and then returned to Romania to become anti-Russian nationalists (T. 3. P. 660), but obviously they made no scholarly contribution to the study of history in Russia.

\section{Volume 4 (1966): OCTOBER 1917 TO THE Mid 1930S}

As promised in Volume Three, Volume Four added sub-chapters on additional states: Turkey, India, and Korea.

The editors announced that special and auxiliary disciplines would be discussed for this period in the next volume, but ultimately they were not (T. 4. Pp. 3-4). In her «Introduction» Nechkina informed readers that subsequent volumes would carry the analysis down to the fiftieth anniversary of the revolution, to 1967 (T. 4. P. 5). There was only one subsequent volume. Discussing Marxist-Leninist methodology and theory, Cherepnin announced that a special volume of Ocherki istorii istoricheskoy nauki $v$ SSSR would be devoted to bourgeois literature from the Ukraine, Belarus, and the Caucasus (T. 4. P. 164. Note 98). Such a volume never appeared. The omission of the Baltic states from this volume was neither explained nor relegated to a future volume; the Baltic countries were not part of the Soviet Union from 1917 to 1941. Central Asia was part of the Soviet Union during the period covered by this volume; perhaps it was intended to include them in the supplemental volume on Ukraine, Belarus, and the Caucasus, but the editors did not say so.

The survey of historical scholarship on Rus'/Russia during the period of «feudalism» by Zimin and Preobrazhenskiy (T. 4. Pp. 271-308) encompasses both early non-Marxist and later Marxist publications and contains innumerable astute comments on well-known monographs. It makes no bones about the idealization of Ivan IV and autocracy in the works of Platonov and Vipper (T. 4. P. 280) but does not explicitly relate their publication to Stalin or the Cult of Personality.

Material in multiple chapters illustrates what is well-known but perhaps not fully appreciated, that not only did some bourgeois historians remain in the Soviet Union after 1917 and continue to teach non-Marxist historiography, but that they also continued to publish, because the Communist Party and government had not yet shut down all non-government publishing houses and imposed ideological censorship on historical works. Non-Marxist historians such as Platonov, Lyubavksiy, Bogoslovskiy, and Presnyakov represented the Soviet Union at international historical conferences in Berlin and Oslo during the 1920s along with historians who were not yet but would become Marxists such as Picheta, Preobrazhenskiy, and maybe Tarle. Fadeev on foreign policy notes that in the 1920s Platonov was still lecturing his students on foreign policy from a bourgeois monarchist point of view (T. 4. P. 436). By the time of the 1932 Hague and Warsaw international historical conferences there were no non-Marxists in the delegation from the Soviet Union (T. 4. Pp. 177-179), although Volume Four does not acknowledge that change. Danilova, evaluating Soviet scholarship on medieval Russia in Volume Five, states forthrightly that after the late 1920s and early 1930s, only (my emphasis-CJH) Marxist scholarship existed in the Soviet Union (T. 5. P. 110). 
The rehabilitation of Pokrovskiy recognized in Volume Three reached full fruition in Cherepnin's chapter on him in Volume Four (T. 4. Pp. 180-198). Pokrovskiy's policy and scholarly errors, contradictions, and flaws could not impugn his enormous scholarly and institutional contributions to Soviet historical science. Besides, Cherepnin observed, some of his errors were not his alone but products of the period's difficulties. In the last analysis, Cherepnin wrote poetically, Pokrovskiy «belonged to history». The subsequent chapter on institutional development of historical studies by Alekseeva and Ivanova confirmed Cherepnin's judgment on Pokrovskiy's administrative activities (T. 4. Pp. 199-268). In a subchapter on $19^{\text {th }}$-century social and economic history, Ryndzyunskiy's analysis of Pokrovskiy's weird ideas about Russian economic history constitutes virtually impenetrable Marxist scholastic exegesis of the categories of capitalism and feudalism (i. e. natural economy) (T. 4. Pp. 308-313).

Emigres continued to be scorned. Writing about Greece and Rome during Antiquity, Utchenko berated the former liberal and emigre White-Guardist Rostovtsev (T. 4. Pp. 577-578). The medievalist Petrushevskiy gets off lighter by Lerner because he stayed and trained Soviet Marxist historians, even as he continued to write anti-Marxist history (T. 4. Pp. 601-604, 609-612). Udal'tsova on Byzantine studies notes that the reactionary Fedor Uspenskiy stayed but eventually in the late 1920s Vasiliev emigrated (T. 4. Pp. 616, 621-22).

\section{Volume Five (1985): Mid 1930s to The End of the 1960s}

Volume Five contains no separate chapters or sub-chapters on any of the union republics or nationalities. Instead, fairly frequently discussion of scholarship about their history during the given period is integrated into the main argument about Russian historiography and Russian history at the time. The editors announced that a separate volume of the series would be devoted to the historiography of the Union republics (the volume on Ukraine, Belarus, and the Caucasus promised by Nechkina?) and that another volume would deal with Soviet historiography on world history, which would include ancient, medieval, early modern, and modern history (T. 5. P. 30. Note *; P. 30. Note **). These volumes, like the volume on auxiliary historical disciplines, also omitted from Volume Five, never appeared.

Volume Five appeared in print just as Gorbachev began his policy of «reconstruction» (perestroika), which was apparently decisive in its long-delayed appearance but not entirely determinative of its content. The delay in publication arose from the neo-Stalinist backlash against the series' engagement in de-Stalinization, and especially against its editor-in-chief, Nechkina ${ }^{15}$.

In covering Soviet historiography during this period, the contributors to the volume frequently had to make mention of their own publications. Apparently no one was concerned about a conflict of interest in doing so. The authors refer to themselves in the third person.

Cherepnin in Chapter 1 praised the end of the one-sided approach to Pokrovskiy of the late 1930s which ignored his contributions but was corrected during the 1950s and 1960s (T. 5. Pp. 6-7). Pokrovskiy's name as a good Bolshevik was restored, despite his errors. His selected works were reprinted (T. 5. P. 34). Similarly Stanislavskaya writing about foreign policy finds the criticism of Pokrovskiy's views one-sided and exaggerated but still serious

${ }^{15}$ Halperin, C. J. Stalin and an Artifact of Soviet Historiography // Journal of Modern Russian History and Historiography. 2020. Vol. 13. No. 1. Pp. 404-413. 
(T. 5. Pp. 295-297). On later foreign policy Emets takes exception to Prokrovskiy's blaming only Russia for the Russo-Japanese War and World War I, minimizing German war guilt for World War I at the same time as Germany was already preparing to launch World War II (T. 5. P. 360).

According to Cherepnin in Chapter 1, after 1956 Soviet historiography overcame the exaggerated progressive significance assigned to Ivan IV's oprichnina during the late 1940s, creating a more objective and comprehensive appreciation of that institution, although most historians rejected some of the assertions of Dubrovskiy, who initiated reconsideration of Ivan IV's historical legacy in 1956 (T. 5. Pp. 29, 31-32) ${ }^{16}$.

Danilova's lengthy exposition of Soviet scholarship on medieval Russia (T. 5. Pp. 110-186) does an excellent job of debunking the «decisive, even hyperbolic significance» ascribed to the oprichnina in works which idealized Ivan IV. She calls particular attention to the works of Veselovskiy as the exception at the time. Veselovskiy returned to Klyuchevskiy's theory that the oprichnina was irrational (an idea she does not dismiss out of hand), and accurately notes that Veselovskiy's views were ignored during his lifetime but acquired considerable influence during the 1960s (T. 5. Pp. 138-141). Concerning Makovskiy's thesis of capitalist development in Muscovy aborted by Ivan IV's oprichina, Danilova makes the astute observation that Makovskiy generalized from data on the most advanced regions of the Muscovite economy and exaggerated the prevalence of production for sale and wage labor in Muscovy when both preceded capitalism anyway. Still, she finds Makovskiy's monograph to be a positive contribution to historiography (T. 5. Pp. 168-169). Danilova deems Dubrovskiy's debunking of Ivan IV, despite some exaggerations, on the whole «well-founded and timely». She emphasizes change in Soviet views during the 1960s, by Zimin, whose conclusions on the oprichnina she accepts, and Skrynnikov, who disagreed with the prevailing consensus on Ivan IV far more than Zimin (T. 5. Pp. 176-177). She laments the failure to integrate archeological evidence into the historical picture of Muscovite history and the absence of much systematic comparison of Russia and the West at the time (T. 5. P. 180). She considers excessive insistence on Russia's similarity to Europe a reaction to the pre-Revolutionary obsession with Russian uniqueness (samobytnost') (T. 5. P. 183) but proposes that the solution lies in borrowing the notion of the Asiatic Mode of Production from [nota bene-CJH] foreign and Soviet oriental studies (T. 5. Pp. 183-184) ${ }^{17}$.

Discussing late feudalism in Russia, Danilova and Klokman almost humorously denigrate those historians who concluded that the peasant uprising during the Time of Troubles dealt a serious blow to feudalism (meaning serfdom), when feudalism (meaning serfdom) continued to exist for another 250 years (T. 5. Pp. 227-228).

Zak on cultural construction declares that the classification system of intelligentsia during the Cultural Revolution was incorrect and too dogmatic (T. 5. P. 570) and that the Communist Party overcame the sectarian and dogmatic leaders of the Proletkult (T. 5. Pp. 571-575).

${ }^{16}$ Perrie M. The Cult of Ivan the Terrible in Stalin's Russia. New York, 2001. P. 179-191. Perrie voices the same conclusion about the reaction to Dubrovskiy's revisionist interpretation of the reign of Ivan IV.

${ }^{17}$ Invocations of the Asiatic Mode of Production flew in the face of orthodox Soviet insistence on the five-stage conception of societal evolution (patriarchal, slave-owning, serfdom, capitalist, socialist) (Markwick R. D. Rewriting History... P. 155-196). Except for Danilova, that conception reigns supreme in «Ocherki istorii istorichestkoy nauki v SSSR». 
Cherepnin in Chapter 1 described post World War II Soviet scholarship as opposing «bourgeois cosmopolitanism and nationalism» (T. 5. P. 12). Criticism of bourgeois historiography in the late 1940s and early 1950s overlooked the contributions bourgeois historians made to historiography. He added that according to critical reviews of Volume One of Ocherki istorii istoricheskoy nauki v SSSR, two of its weaknesses were a one-sided bias against pre-Marxist scholarship as unscientific and neglect of the ties between Russian and European historiography (T. 5. Pp. 20-21). Cherepnin did not mention anti-Semitism, Great Russian chauvinism, or xenophobia as characteristics of Zhdanovshchina. Danilova, in discussing scholarship on medieval Russia, wears similar blinders in identifying the problem with the discussion of cosmopolitanism as the attempt to show that Russia had never been inferior to the most advanced countries of Europe (T. 5. P. 124).

\section{Conclusion}

The five-volume Ocherki istorii istoricheskoy nauki $v$ SSSR is a predictable and frequently tendentious but fascinating relic of Soviet historiography, displaying its organizational strength and abundance of high-quality historical expertise. It also provides fascinating insights into Soviet historiography.

As a whole, all the volumes of the series display a consistent point of view. (Danilova on the Asiatic Mode of Production is a conspicuous exception.) This is hardly accidental. However, even in the late 1930s, and especially after 1956, Soviet historians, despite centralized authoritarian control, managed to disagree with each other most of the time, albeit least of all during the purges and the post-war years up to Stalin's death. The project remained incomplete. At least three volumes - on nationalities, world history, and auxiliary historical disciplines - remained to be written. Of these perhaps the most missed would be the last. Ocherki istorii istoricheskoy nauki $v$ SSSR provides intriguing insights into Soviet historiography during the post-Stalin and pre-perestroika period of Soviet history.

\section{Appendix 1: Contributors}

$\begin{array}{lrlrlr}\text { Author } & \text { Volume(s) } & \text { Author } & \text { Volume(s) } & \text { Author } & \text { Volume(s) } \\ \text { Akatova, A. I. } & 2,3 & \text { Danilov, V. P. } & 2,3,5 & \text { Gasanov, I. M, } & 2,3 \\ \text { Akhramovich, R. T. } & 4 & \text { Danilova, L. V. } & 4,5 & \text { Gimadi, Kh. G. } & 2 \\ \text { Alaev, L. B. } & 4 & \text { Derenkovskiy, G. M, } & 5 & \text { Gintsberg, L. I. } & 4 \\ \text { Alatortseva, A. I. } & 5 & \text { Dyadichenko, V. A. } & 1 & \text { Golikov, G. N. } & 4 \\ \text { Alekseeva, G. D. } & 3,4,5 & \text { Donosov, I. K. } & 1 & \text { Gorbunov, V. V. } & 4 \\ \text { Aleskerzade, A. A. } & 1 & \text { Draudin, T. Ia. } & 1,2,3 & \text { Gorodetskiy, E. N. } & 3,4,5 \\ \text { Alizade, A. A. } & 1 & \text { Dubrovskiy, S. M. } & 3 & \text { Grave, B. B. } & 3 \\ \text { Alpatov, M. A. } & 1,2,3 & \text { Dunaevskiy, V. A. } & 3,4 & \text { Guliamov, Ia. G. } & 1 \\ \text { Artsikhovskiy, A. V. } & 1,2,3 & \text { El'chibekyan, A. M. } & 2,3 & \text { Guliev, A. N. } & 1,2,3 \\ \text { Berkhin, I. B. } & 4,5 & \text { Emets, V. A. } & 5 & \text { Ibragimov, Z. I. } & 1 \\ \text { Beskrovniy, L. G. } & 1 & \text { Erusalimskiy, A. S. } & 3 & \text { Ignatenko, T. A. } & 5 \\ \text { Boyko, I. D. } & 1 & \text { Fadeev, A. V. } & 4 & \text { Illeritskiy, V. E. } & 1,2,3 \\ \text { Borozdin, I. N. } & 1 & \text { Gabashvili, V. N. } & 1,2,3 & \text { Ioffe, A. E. } & 4,5 \\ \text { Cherepnin, L. V. } & 2,3,4,5 & \text { Galkin, I. S. } & 3 & \text { Ioninas, I. Z. } & 1,2,3 \\ \text { Chistyakov, O. I. } & 5 & \text { Gal'perin, A. L. } & 1,2,3 & \text { Ismailov, M. A. } & 1\end{array}$


Author

Itenberg, B. S. Ivanova, L. V.

Kafengauz, B. B.

Kalugina, A. M.

Kandel', E. P.

Karyev, A. K.

Kashtanov, S. M.

Khachikian, L. S.

Kheifets, M. I.

Klokman, Yu. G.

Koblents, I. N.

Kondratyev, V. A.

Konyushaya, R. P.

Korostovtsev, M. A.

Kovalenko, L. A.

Kovalenko, V. A.

Koz'min, B. P.

Kudryavtsev, F. A.

Kuliev, O. 1.

Kuz'min, N. F.

Kuznetsova, N. A.

Laigna, K. V.

Laul, E. I.

Laverychev, V. Ia.

Lel'chuk, V. S.

Lerner, I. Ia.

Lisovskiy, P. A.

Lopukhov, B. R.

Makhnova, G. P.

\section{Volume(s) Author}

5 Man'kovskaya, I. L.

4, 5 Mashkin, N. A.

1 Maslov, N. N.

4 Mitrofanova, A. V.

4 Mogil'nitskiy, B. G.

1 Mogil'nitskiy, N. A.

2,3 Mokhov, N. A.

1 Nabiev, R. N.

3, 4 Naumov, V. P.

5 Nechkina, M. V.

2, 3 Nepomnin, V. Ia.

3 Nikiforov, V. N.

2 Nikitin, S. A.

2,3 Nikonova, S. V.

1,2

3

2

2

2

3

4

4

1

3

4,5

4,5

4

4 Ryndzyunskiy, P. G.

4 Semenov, A. A.

5 Shabunia, K. I.

Pertsev, V. N.

Podpalova, G. A.

Polevoy, Yu. Z.

Postnikov, V. V.

Postovskaya, N. M.

Putnyn', E. E.

Rubinshtein, N. L.

Rudnitskaya, E. L.

\section{Volume(s) Author}

Volume(s)

4 Shakhmatov, V. F.

$1,2,3$

2,3 Shastina, N. P.

5 Shipaev, V. I.

3,4

5 Sipols, V. Ya.

2 Sivkov, K. V.

3 Smirnov, N. A.

$1,2,3,4$

2,3 Stanislavskaya, A. M. 2, 3, 5

1 Strigunov, I. V.

5 Sumbatzade, A. S.

3

3, 4 Tarnovskiy, K. N.

2, 3 Tikhomirov, M. N.

3, 4 Tokarev, S. A.

1,2,3 Tokarshevskiy, E. A.

4 Udal'tsova, Z. V.

1 Ugarov, I. F.

Predtechenskiy, A. V.

Preobrazhenskiy, A. A.

1, 2, 3 Utchenko, S. L.

4 Veber, B. G.

2 Yakovlev, N. N.

4 Yampol'skiy, A. I.

4 Yanin, V. L.

1 Yansen, E. A.

4 Yatsunskiy, V. K.

2, 3 Vyazigin, S. A.

1 Volin, M. S.

5 Zak, L. M.

4, 5 Zhyugzhda, Yu. I.

1, 2, 3 Zimin, A. A.

3 Zverev, V. A.

$$
\text { 4, } 5
$$

$1,2,3$

$1,2,3,4$

4,5

2, 3

4

1

2,3

3

$1,2,3$

3, 4

5

3

4

5

Информация о статье

Автор: Гальперин, Чарльз - доктор истории, внештатный историк, Университет Индианы, Блумингтон, США, OrcID 0000-0002-6667-0555; e-mail: chalperi@iu.edu

Название: An artifact of Soviet historiography: Ocherki istorii istoricheskoy nauki v SSSR [Артефакт советской историографии: «Очерки истории исторической науки в СССР»]

Резюме: Пятитомное, но незаконченное издание «Очерки истории исторической науки в СССР», вышедшее в период с 1955 по 1985 гг., представляет собой увлекательный артефакт советской историографии. Это яркое напоминание о способности советской историографии мобилизовать по команде опыт и финансовые ресурсы, необходимые для создания коллективных многотомных серий. «Очерки истории исторической науки в СССР» охватили историю всех народов, проживавших на территории СССР после Второй мировой войны. В этой статье данный проект рассматривается с технической точки зрения.

Ключевые слова: СССР, историография, М. Н. Покровский

Литература, использованная в статье:

Очерки истории исторической науки в СССР. Т. 1 / Ред. М. Н. Тихомиров (отв. ред.) и др. Москва: Издательство АН СССР, 1955. 692 с.; Т. 2 / Ред. М. В. Нечкина (отв. ред.) и др. Москва: Издательство АН СССР, 1960. 852 с.; Т. 3 / Ред. М. В. Нечкина (отв. ред.) и др. Москва: Издательство АН СССР, 
1963. 832 с.; Т. 4 / Ред. М. В. Нечкина (отв. ред.) и др. Москва: Издательство АН СССР, 1966. 854 с.; Т. 5 / Ред. М. В. Нечкина (отв. ред.) и др. Москва: Наука, 1985. 606 с.

Byrnes, Robert F. Some Perspectives on the Soviet Ferment Concerning Soviet History // Facing Up to the Past: Soviet Historiography under Perestroika / Ed. Takayuki Ito. Sapporo, Japan: Slavic Research Center, Hokkaido University, 1989. P. 11-19.

Enteen, George M. Soviet Historians Review Their Own Past: The Rehabilitation of M. N. Pokrovsky // Soviet Studies. 1969. Vol. 20. No. 3. P. 306-320.

Halperin, Charles J. Stalin and an Artifact of Soviet Historiography // Journal of Modern Russian History and Historiography. 2020. Vol. 13. No. 1. Pp. 404-413.

Halperin, Charles J. Zakhvatchiki, Soviet Historiography, and the Tatars: A Note // Vestnik SanktPeterburgskogo gosudarstvennogo universiteta. Seriya 2: Istoriya. 2019. Vol. 64. No. 4. Pp. 1429-1439.

Markwick, Roger D. Rewriting History in Soviet Russia: The Politics of Revisionist Historiography, 19561974. Houndmills, Basingstoke, Hampshire: Palgrave, 2001. 327 p.

Perrie, Maureen. The Cult of Ivan the Terrible in Stalin's Russia. New York: Palgrave, 2001. 255 p.

Yurchak, Alexei. Everything Was Forever, Until It Was No More: The Last Soviet Generation. Princeton: Princeton University Press, 2006. 352 p.

Information about the article

Author: Halperin, Charles J. - PhD in History, Research Associate, Indiana University, Bloomington, Indiana, USA, OrcID 0000-0002-6667-0555; e-mail: chalperi@iu.edu

Title: An Artifact of Soviet Historiography: Ocherki istorii istoricheskoy nauki v SSSR

Summary: The five-volume but incomplete Ocherki istorii istoricheskoy nauki v SSSR published between 1955 and 1985 is a fascinating artifact of Soviet historiography. It is a palpable reminder of the ability of Soviet historiography to mobilize by command the expertise and financial resources required to produce multi-author multi-volume series. Ocherki istorii istoricheskoy nauki v SSSR encompassed the histories of all peoples living on the territory of the USSR after World War II. This article examines the project from a mostly technical point of view.

Keywords: USSR, historiography, journal

\section{References:}

Byrnes, Robert F. Some Perspectives on the Soviet Ferment Concerning Soviet History, in Ito, Takayuki (ed.). Facing Up to the Past: Soviet Historiography under Perestroika. Sapporo, Japan: Slavic Research Center, Hokkaido University Press, 1989. Pp. 11-19.

Enteen, George M. Soviet Historians Review Their Own Past: The Rehabilitation of M. N. Pokrovsky, in Soviet Studies. 1969. Vol. 20. No. 3. Pp. 306-320.

Halperin, Charles J. Stalin and an Artifact of Soviet Historiography, in Journal of Modern Russian History and Historiography. 2020. Vol. 13. No. 1. Pp. 404-413.

Halperin, Charles J. Zakhvatchiki, Soviet Historiography, and the Tatars: A Note, in Vestnik SanktPeterburgskogo gosudarstvennogo universiteta. Seriya 2: Istoriya. 2019. Vol. 64. No. 4. Pp. 1429-1439.

Markwick, Roger D. Rewriting History in Soviet Russia: The Politics of Revisionist Historiography, 19561974. Houndmills, Basingstoke, Hampshire: Palgrave Publ., 2001. 327 p.

Ocherki istorii istoricheskoy nauki v SSSR [Studies of the history of historical science in the USSR]. T. 1. Ed. by M. N. Tikhomirov (Responsible Editor) et al. Moscow: Academy of Sciences of the USSR Press, 1955. 692 p.; T. 2. Ed by M. V. Nechkina (Responsible Editor) et al. Moscow: Academy of Sciences of the USSR Press, 1960. 852 p.; T. 3. Ed. by M. V. Nechkina (Responsible Editor) et al. Moscow: Academy of Sciences of the USSR Press, 1963. 832 p.; T. 4. Ed. by M. V. Nechkina (Responsible Editor) et al. Moscow: Academy of Sciences of the USSR Press, 1966. 854 p.; T. 5. Ed by M. V. Nechkina (Responsible Editor). Moscow: Nauka Publ., 1985. 606 p. (in Russian).

Perrie, Maureen. The Cult of Ivan the Terrible in Stalin's Russia. New York: Palgrave Publ., 2001. 255 p. Yurchak, Alexei. Everything Was Forever, Until It Was No More: The Last Soviet Generation. Princeton: Princeton University Press, 2006. 352 p. 